\title{
Diāna Ritere
}

\section{Emocijas un afekts: vārdos, izjūtās, vērtējumos \\ Emotions and affect: In words, feelings, evaluations}

\begin{abstract}
Due to the cultural specificity and variation of emotions, it is important to study them in different languages, cultures and contexts. The aim of the study is to summarize the most widespread words of emotions in the Latvian language, to map them in the dimensions of valence and activation, and to link them with the selfassessment indicators of bodily senses such as valence and activation.

The results point to sometimes consistent assessments of emotions in senses, dimensions and words in the Latvian language, as well as perspectives in further research with implications for improving various affective computing and sentiment analysis technologies.
\end{abstract}

Keywords: emotions, valence, activation, language, physiological self-assessments.

\section{levads}

Afekts ir virstermins dažādām vērtējošām pieredzēm cilvēkā; tās atšḳiras intensitātē, ilgstošumā, sinhronitātē, fokusētībā uz notikumu, novērtējuma izdibināšanā, izmaiṇu straujumā un uzvedības ietekmēšanā; no šiem rādītājiem emocijas kā afekta paveids nav ilgstošs, tomēr ir izteikts pārējos aspektos [Karunaratne, Atukorale and Perera 2011: 490]. Emocijām daudzās kultūrās izšḳir 2 dimensijas, pēc kurām strukturējamas raisītās izjūtas, t. i., valence (hedoniska; raksturo patikas apmēru pret 
pieredzes objektu) un aktivācija (raksturo iesaisti un aizraušanos iepretim neieinteresētībai, miegainībai) [Russell 1980: 1163-1168]. Domāt par emocijām kā daudzdimensionālām ir likumsakarīgi, jo pastāv uzskats, ka emocijas ir veidotas no sīkākām dal̦ām, piemēram, pamata afekts (core affect) tiek aprakstīts kā pirmatnējs un vienkāršāks apziṇas elements, kas piedalās emociju veidojošajā pieredzē [Barrett and Bliss-Moreau 2009: 170-188], vienlaicīgi esot nereflektīva izjūta, kas sastāv no hedonisma un uzbudinājuma vērtībām [Russell 2003: 147]. Tādējādi emocijas ne vienmēr ir statiskas; drīzāk tās ir laikā dinamiski un situatīvi novērtējumi, kas mainās līdzvērtīgi kontekstam.

Emocijas var klasificēt pēc vairākām komponentēm: kognitīvās, neirofizioloǵiskās un motivācijas komponentes, kā arī motorās ekspresijas komponentes un pēc subjektīvām izjūtām [Scherer 2005: 698-700]. Emocijām papildus piemīt dažādas izpausmes - izjūtas (psihisks stāvoklis, kam raksturīga emociju notikuma apzināšanās), sejas muskulatūras kustības, vokalizācijas, autonomās nervu sistēmas izmaiṇas [Barrett 2006: 46].

Emociju pieredzi var izjust un ekspresīvi izrādīt, taču no pirmā obligāti neizriet otrais. Ja persona jūtas, piemēram, skumji, tā var apzināti nolemt, vai to izrādīt ar vokalizāciju, valodu, sejas izteiksmi, žestiem vai citām motoriskām darbībām. Tas vienlaikus paredz, ka emocijas nav vienmēr tas pats, kas ir izjūtas, taču ir pakārtotas tām - to izskaidro tas, ka dažas izjūtas var norisināties nekontrolēti un bez augstāku kognitīvu līmeṇu apstrādes. Emociju ekspresijai var būt sociāla funkcija, t. i., paužot citiem savas emocijas, to var darīt dažādi un gūt atšḳirīgu rezultātu atkarībā no emociju paudēja un situācijā iesaistītās personas (-ām), kā arī no kontekstuāliem faktoriem [Van Kleef and Côté 2007: 1562-1567]. Līdz ar to emocijām ir piederības un distancēšanās funkcija.

Kopumā var teikt, ka emocijām ir vairākas izpausmes, kas emocionālās instances realizēšanas un izjušanas brīdī visas vai gandrīz visas ir savstarpēji sinhronizētas, lai ḷautu organismam adaptīvi reaǵēt vai prognozēt ārējās vides ierosinātu sensoro datu stimulāciju. Tādējādi saprotams, ka emocijas ir svarīga ikdienas komponente, kas virza darbību un var ietekmēt spriešanu, kā arī iesaistās sociokulturālos procesos, no tiem vienlaikus gūstot un tos ietekmējot atškirīgā pakāpē dažādos laika posmos. 


\section{Valoda un afektīvi stāvokḷ!i}

Cilvēki kategorizē atšḳirīgus objektus, stimulus un parādības, pien,emot, ka tiem ir vienāda funkcionāla nozīme. Kategorizācija var notikt pēc tādiem atribūtiem un īpašībām kā krāsa, forma, objekta funkcijas u. c. Kategorijas var strukturēt hierarhiskos līmen,os, tātad tai var būt pamata līmenis, kurš ar savu atribūtu klāstu producētu vislielāko saistīto kategoriju klasteri; papildus tam tieši šis līmenis kognitīvai apstrādei būtu heiristiski pieejamāks [Rosch 1978: 328-350].

Uztveramas un abstraktas vienības iespējams kārtot dažādās kategorijās, n,emot vērā sociokulturālu kontekstu, proti, tas, kāds lietojums ir uztveres objektam, ir atkarīgs no sociāli un kulturāli gūtas sapratnes par pieṇemtajām normām. Literatūrā [Barrett 2014: 293] pozicionēts, ka "fiziskas izmainas dabiskajā pasaulē [..] kḷūst par emocijām, kad tās tiek kategorizētas, [iekšēju fizikālu un sensoro izmaiṇu] uztvērējam izmantojot savas konceptuālās zināšanas par emocijām”. Rezumējot ir saprotams, ka kategorijas tiek veidotas no dažādām afektīvām instancēm, un ar laiku personai rodas konceptuāla izpratne par kādu emociju dažādās tās izpausmēs un brīžos, savukārt konceptus ir iespējams atkārtoti piemērot, interpretējot jaunās situācijas kontekstuālos un sensoros ievaddatus.

\section{Variācija}

Pienemts uzskatīt, ka emocijas ir ad hoc kategoriju koncepti, t. i., tās ir specifiskas situācijai un veicamajam uzdevumam [Hoemann, $X u$ and Barrett 2019: 1831-1841]. Šādus konceptus ir nepieciešams uzkrāt un lietot, lai mazinātu prognostiskas kḹūdas, kas var rasties, interpretējot lielu daudzumu sensoru ievaddatu. Piemērojot situācijai atbilstošu kategoriju, vienlaicīgi var reprezentēt emociju konceptu, ar ko var saprast jau ǵeneralizētāku skatījumu par situācijā implementējamo darbību kopumu. Paralēli emocijas var skatīt kā cilvēka resursu mobilizējošu instrumentu: secīgi argumenti un skrupuloza spriešana ikdienas situācijās var būt kognitīvi prasīga un patērēt daudz laika, tāpēc veiksmīgi un dinamiski regulētas emocijas savā ziṇā ir kā heiristika jeb îsceḷš dažādu problēmu risināšanai. 
Ciešā pakārtotība kontekstuāliem un situatīviem faktoriem emociju pieredzi padara l̦oti variatīvu - gan vienas emocijas instancē (priecāties var dažādās izpausmēs un pakāpēs), gan dažādos cilvēkos (divi cilvēki var priecāties atškirī̄gi un dažādās situācijās) un kultūrās [Jackson et al. 2019: 1715-1722]. Šādā ziṇā ir jēgpilni pētīt ne tikai emociju vārdus, par kuriem var būt vienprātība, bet arī fizioloǵiskus rādītājus, kuri atšḳiras lokalizācijā, intensitātē, ilgumā un pakḷaujas atšḳirīgiem emociju regulācijas procesiem.

Šì pētījuma mērḳis ir konstatēt, 1) vai un kādi emociju vārdi latviešu valodā prevalē; 2) cik izplatīti tie ir starp respondentiem; 3) kā emociju vārdi tiek novērtēti pēc valences un aktivācijas skalām; 4) kāda ir variācija abās skalās; 5) kādi ir k̦ermeniskie pašnovērtējumi dažām no emociju kategorijām (un cik izkliedēti tie ir). Pētījuma novitāte aktualizēta tajā, ka līdz šim emociju kategoriju kultūrspecifiski pētījumi Latvijas kontekstā nav izplatīti, kā arī emociju daudzdimensiju semantiskā telpa latviešu valodā līdz šim nav veidota un apkopota.

\section{Metode}

\subsection{Pētījuma dalībnieki}

Pētījumā piedalījās vīrieši un sievietes $(n=53)$ vecumā no 19 līdz 43 gadiem. Vidējais vecums sieviešu grupā bija 25,04 gadi ( $n=33$, $S D=6,08$ ), vīriešu grupā vidējais vecums bija 27,33 gadi ( $n=17$, $S D=6,55)$. No 53 cilvēkiem 46 bija ieguvuši vai tobrīd ieguva augstāko izglītību. Izlase tika atlasīta pēc pieejamības principa, aptauju izvietojot dažādās interneta un tiešsaistes saziṇas vietnēs.

\subsection{Instrumentārijs}

Pētījumā tika izmantoti 27 emociju inducējoši video fragmenti [Cowen \& Keltner 2017], kas atlasīti pēc to dažādās valences. Respondenti sākotnēji aizpildīja Zviedru kodola afekta skalu [Swedish Core Affect Scale; Västfjäll, Friman, Gärling, Kleiner, 2002; latviešu valodas adaptācija, Vanags, Raščevska, 2015], noskatījās vienu no video fragmentiem un tika lūgti nosaukt vienā vārdā/frāzē emociju, ko izjūt pēc tā noskatīšanās 
("Novērtējiet vienā vārdā vai frāzēe kādu emociju izjūtat!"), kā arī no 1 līdz 3 punktiem cilvēka trafaretā atzīmēt, kur izjūt šo emociju ("Atzīmējiet, kurā vietā savā kermenī visvairāk izjūtat šo emociju!”), un atzīmēt 9 punktu Likerta skalā valences un aktivācijas rādītājus.

Respondenti aptauju pildīja QuestionPro aptauju rīkā. Visi respondenti tika lūgti sniegt apliecinājumu informētai piekrišanai par dalību pētījumā.

\subsection{Datu sagatave}

Dati tika apstrādāti lietotnē RStudio. Lai analizētu emociju vārdus, tie vispirms tika apstrādāti tā, lai katram vārdam nebūtu ne galotnes, ne piedēkḷa, tādējādi saglabājot vārda sakni un/vai priedēkli. Tas veikts, lai analizētu vienādus mērījumus, kas potenciāli atšḳiras maznozīmīgi, piemēram, vārds dažādās dzimtēs (priecīgs/priecīga) vai dažādos vispārinājumos (silti/siltums).

\subsection{Rezultāti}

Kopā tika producētas 1383 lingvistiskas vienības. Pēc nederīgu vienību filtrēšanas kā vairāki vārdi (nevis viens vārds) un/vai gari teikumi datu kopā bija 1234 vienības; no tām unikālas - 296. Turpmākos aprēḳinos tika iekḷauti vārdi, kurus respondenti minējuši vismaz 2 reizes, kas novērots 75 lingvistisku vienību gadījumā.

Aprēḳinot vidējos rādītājus valences un aktivācijas skalās, redzams, ka izlase ar zināmu vienprātību un saskaṇotību vērtējusi emociju vārdus latviešu valodā. Novērojams tas, ka negatīvas emocijas tiek vērtētas valences skalā zemāk un pozitīvas emocijas valences skalā - augstāk (sk. 1. pielik.). Pēc valences rādītājiem, viszemāk vērtēts vārds šausmas (dažādās ši un turpmāko vārdu formās) $(-3,78)$, izmisums $(-3,67)$, riebums $(-3,6)$. Visaugstāk valences skalā vērtēti: uzticība $(4)$, cerība $(3,8)$, jautrība $(3,75)$. Visaugstāk aktivācijas skalā vērtēti vārdi nobijies (-usies) $(3,6)$, uztraukums $(2,76)$, smaids $(2,8)$, bet viszemāk - miegainība $(-3,7)$, vienaldzība $(-1,75)$.

Daži no vārdiem tiek pieminēti vairāk reižu (sk. 1. un 3. pielik.). To var novērot situācijā ar, piemēram, prieks (73 gadījumos), bailes (61), pretīgums (53), riebums (40), pārsteigums (34), apbrīna (37) u. c. 
2. pielikumā redzams, ka kopumā mazāka vērtējumu variācija novērojama valences, nevis aktivācijas skalās. Vismazākā valences vērtējumu variācija novērojama tādiem negatīviem emociju vārdiem kā šausmas, riebums, pretīgums, nepatīk, bailes; pozitīviem vārdiem mazākā variācija novērojama vārdiem siltums, prieks, apmierinājums, laime. Vislielākā valences variācija novērojama tādiem negatīviem vārdiem kā šoks, skumjas, apjukums, līdzjūtība; pozitīviem - izbrīna, interese, pārsteigums, atvieglojums. Aktivācijas skalā nav novērojama liela vienprātība un pārsvarā prevalē liela vērtējumu variācija. Gandrīz visi aprēḳinos iekḷautie emociju vārdi ap mediānu ir stipri izkliedēti uz abiem skalas poliem. Vismazākā variācija novērojama vārdiem riebums, nepatīk, šoks. Vislielākā variācija abās skalās novērojama tādiem vārdiem kā atvieglojums, pārsteigums, izbrīns, līdzjūtība, vienaldzība.

Lielākoties dotajā datu kopā nav novērojama situācija, kurā lielāka variācija rodas, palielinoties vienību skaitam (gadījumā ar prieks un bailes, jo šo vārdu valences rādītāji ir tuvu mediānai).

Ķermenisko izjūtu pašnovērtējumos (sk. 3. pielik.) sarkanos apgabalos atzīmētas pēc novērtējuma skaita visblīvākās k̦ermeṇa dalas, kur izjusta minētā emocija, savukārt zaḷajos apgabalos novērojamas mazāk blīvas daḷas. Novērojams, ka ikvienā no minētajām emociju pieredzēm vismaz viens no epicentriem ir galva, nākamā - krūšu un/vai kakla daḷ. Lielākoties tādas negatīvas emocijas kā bailes, satraukums, trauksme, riebums, dusmas ir izkliedētas pa lielāko k̦ermen, daḷu. Pozitīvu emociju lokalizācija pārsvarā ir norādīta sejā un krūtīs, kā, piemēram, miera, mīluma, apbrīnas gadījumā. Ar tādu hedoniski ambivalentu vārdu kā vienaldzība vai apjukums redzama liela izkliede un nesaskanīga punktu izvēle starp visiem respondentiem.

\section{Diskusija}

Kopumā pētījuma izlase vērtējusi emociju vārdus latviešu valodā saskanīgi ar valences un aktivācijas skalām, liecinot, ka arī šajā valodā divdimensiju vērtējums ir piemērojams emociju vārdiem. Dažviet ir novērojama līdzīgu vārdu klasterizēšanās tuvās kartes koordinātēs (piem., satraukums, trauksme, uztraukums). Būtisks jautājums turpmākos pētījumos 
būtu kartēto un citu emociju vārdu klasterizācija, kā arī to robežošanās semantiskajā telpā, jo, pretēji valodas diskrētumam, emociju pieredze varētu būt fluīda, izplūdusi [Cowen and Keltner 2017: 6-10].

Novērojams interesants jautājums par vārdu formu un dalı saistību ar emocijām, precīzāk: vai priedēkḷi norāda uz dažādas pakāpes emocionālu piesātinājumu (ja tā, kuriem vārdiem un kurās dimensijās?)? Vai dažāda vispārinājuma vārdi (piem., prieks un priecīgs) ietekmē vērtējumu statistiski nozīmīgi? Pētījumu nākotnes perspektīvā varētu runāt arī par nepopulārāko emociju vārdu kartēšanu un analizēšanu, jo tie potenciāli var sniegt ieskatu izteikti unikālās emociju pieredzes instancēs. Līdztekus varētu risināt jautājumu par to, vai kādi no emociju vārdiem ir aizstājami ar mazāk pieminētiem, taču pēc dimensiju vērtējumiem līdzīgiem vārdiem.

Lielāka variācija novērojama aktivācijas skalās. Tas konsekventi sakrīt ar iepriekšēju pētījumu atziṇām par to, ka nevis hedoniskā jeb valences pieredze emocijās, bet gan aktivācija ir tā, kas, cilvēkam un valodas apguvei attīstoties, tiek izšḳirta rafinētāk [Nook et al. 2017: 881-889]. Novērojams arī tas, ka respondentiem sarežǵītāk "vienoties" par kopīgu valences un aktivācijas mērījumu ir ar neitrālām vai nedaudz ambivalentām kategorijām (piemēram, pārsteigums, jo tas var būt gan pozitīvs, gan negatīvs). Viens no skaidrojumiem varētu būt, ka šīs emociju kategorijas ir kontekstuāli variablas - to viena no svarīgākajām funkcijām būtu nevis afektīva tuvināšanās/attālināšanās stimulam vai objektam, bet to resursu mobilizēšana, kas nepieciešama operatīvai informācijas apstrādei. Tāpēc pamats uzskatīt, ka tieši individuālās emociju regulācijas īpatnības un pieredze nosaka to, kā emocija tiktu vērtēta. Paralēli jābilst, ka ir pierādīts: cilvēki bieži vien pieḷauj kognitīvas kḷūdas, novērtējot savas potenciālās emocijas un izjūtas [Gilbert et al. 1998: 633-636], kas, iespējams, saasinās tādu hedoniski neskaidru situāciju gadījumā kā apjukums, izbrīns, pārsteigums u. tml. Arī tādēl svarīgi pētīt fizioloǵiskus datus - cilvēki kropḷo afekta informāciju ar subjektīvu vērtējumu, kam pēc būtības ir noilgums kaut vai tikai tāpēc, ka valodas un runas producēšana notiek pēc notikuma, par kuru tiek producēta runa.

Cilvēki lielākoties norāda līdzīgas vietas ḳermenī vienu emociju laikā, bet ḳermenisku izjūtu pašnovērtējumu indikācijai ir zināmi mīnusi. Pirmais 
ir potenciāla respondentu neobjektivitāte. Var būt, ka novērtējums ir tikai video fragmenta fizioloǵiska mīmikrija (piem., video fragments ar rokas sasišanu $\rightarrow$ fizioloǵisks indikators rokas reǵionā). Lai arī šāda veida skatījums ir saskanīgs ar tām emociju teorijām, kas postulē, ka emocijas ir subjektīvs situācijas novērtējums, stimula fizioloǵiskās pieredzes pārnese uz paša k̦ermeni būtu precīzs nevis emocijas, bet gan fizikālu īpašību atspoguḷjums. Pastāv arī risks, ka respondents nevar patstāvīgi izjust un vienlaikus fiksēt emociju fizioloǵiskās norises ḳermenī. L̦oti stipri izjūtot emociju krūšu rajonā, var tikt izlaists novērtējums par izjūtām citur, piemēram, sejas rajonā, kaklā, kājās utt. Visdrīzāk sagaidāms tas, ka, palielinoties šo punktu skaitam ḳermenī, ar laika noilgumu iespējams konstatēt salīdzinoši mazāku skaitu lokāciju. Vēl viens trūkums būtu nespēja noteikt minimālas fizioloǵiskas izmaiṇas - iespējams, izmainnas ir tik nelielas, ka tās var fiksēt tikai kādi sensori, piemēram, elektrodermālās aktivācijas mērītājs. Kognitīva apstrāde un analīze par emociju subjektu var pārmākt fizioloǵisko izjūtu fiksēšanu. Otrais mīnuss ir nespēja norādīt, vai izjustais bijis silts (piem., vaigu sarkšana) vai auksts ("dūša papēžos", "no bailēm nobālējis” u. tml.). Šāda veida atšḳirības 1) būtiski maina emocijas pieredzi; 2) visdrīzāk pieprasa citādus emociju regulācijas mehānismus, tādē! būtu jāfiksē ar cita veida mērījumiem [Nummenmaa et al. 2013: 646-651]. Papildus cilvēki ḷoti bieži norāda, ka emociju izjūt sejas rajonā, tomēr nav skaidrs, kā tieši tas notiek. Šajā gadījumā vērtīgi būtu ievākt datus ar miogrāfa palīdzību, jo īpaši tādēl, ka vienā emociju kategorijā var būt ḷti variablas sejas ekspresijas [Barrett et al. 2019: 45-49].

Šādā veida pētījumi par emociju kategorijām ir izmantojami afektīvās skaitḷošanas nozarēs. legūtā lingvistiskā informācija un detalizēti fizioloǵiskie mērījumi var noderēt sentimenta analīzes tehnoloǵiju uzlabošanai. Apkopojot vārdus pēc divām dimensijām, speciālisti var detalizētāk analizēt lietotāju afektīvos stāvokḷus, ko t. sk. var izmantot veselības aprūpē (piem., palīdzot cilvēkiem ar autisma spektra traucējumiem atbilstīgāk kategorizēt emocijas vai arī uzlabojot dialogu sistēmas [Luxton 2014: 332-339].

Sentimenta analīze, kas izmantotu pētījumā apskatītās emociju kategorijas un saistītās dimensijas, varētu tikt lietota mārketingā, klientu apkalpošanā, sociālo mediju ziṇu monitorēšanā, kā arī citās nozarēs, 
kur ir liels datu apmērs, kas norāda uz lietotāja apmierinātību ar sniegto pakalpojumu vai kādu pieredzi. Kombinējot dažāda veida datus vairāk nekā vienā mērījuma dimensijā, pakalpojuma sniedzējam var rasties niansētāka izpratne par to, vai radītais produkts/pakalpojums izraisa tādas emocijas, kā bijis iecerēts. Visbeidzot, nodrošinot afektīvās skaitḷošanas aplikācijas ar detalizētākiem emociju aprakstiem, var veicināt cilvēka un datora mijiedarbības attīstību cilvēkam intuitīvākā, saprotamākā un ērtākā veidā.

\section{Izmantotā literatūra}

1. Barrett, L. F. (2006). Are Emotions Natural Kinds? In: Perspectives on Psychological Science, No. 1 (1), p. 46.

2. Barrett, L. F. and Moreau, E. B. (2009). Affect as a Psychological Primitive. In: Advances in Experimental Social Psychology. Burlington: Academic Press, pp. 170-188.

3. Barrett, L. F. (2014). The Conceptual Act Theory: A Précis. In: Emotion Review, No. 6 (4), p. 293.

4. Barrett, L. F., Adolphs, R., Marsella, S., Martinez, A. M. and Pollak, S. D. (2019). Emotional Expressions Reconsidered: Challenges to Inferring Emotion From Human Facial Movements. In: Psychological Science in the Public Interest, No. 20 (1), pp. 45-49.

5. Cowen, A. S. and Keltner, D. (2017). Self-report captures 27 distinct categories of emotion bridged by continuous gradients. In: Proceedings of the National Academy of Sciences, No. 114 (38), pp. 1-10.

6. Gilbert, D. T., Pinel, E. C., Wilson, T. D., Blumberg, S. J. and Wheatley, T. P. (1998). Immune neglect: A source of durability bias in affective forecasting. In: Journal of Personality and Social Psychology, No. 75 (3), pp. 633-636.

7. Hoemann, K., Xu, F. and Barrett, L. F. (2019). Emotion words, emotion concepts, and emotional development in children: A constructionist hypothesis. In: Developmental Psychology, No. 55 (9), pp. 1831-1841.

8. Jackson, J. C., Watts, J., Henry, T. R., List, J.-M., Forkel, R., Mucha, P. J., Greenhill, S. J., Grey, R. D. and Lindquist, K. A. (2019). Emotion semantics show both cultural variation and universal structure. In: Science, No. 366 (6472), pp. 1517-1522. 
9. Karunaratne, I., Atukorale, A. S. and Perera, H. (2011). Surveillance of human-computer interactions: A way forward to detection of users' Psychological Distress. In: 2011 IEEE Colloquium on Humanities, Science and Engineering Research, p. 490.

10. Luxton, D. D. (2014). Artificial intelligence in psychological practice: Current and future applications and implications. In: Professional Psychology: Research and Practice, No. 45 (5), pp. 332-339.

11. Nook, E. C., Sasse, S. F., Lambert, H. K., McLaughlin, K. A. and Somerville, L. H. (2017). Increasing verbal knowledge mediates development of multidimensional emotion representations. In: Nature Human Behaviour, No. 1 (12), pp. 881-889.

12. Nummenmaa, L., Glerean, E., Hari, R. and Hietanen, J. K. (2013). Bodily maps of emotions. In: Proceedings of the National Academy of Sciences, No. 111 (2), pp. 646-651.

13. Rosch, E. H. (1973). Natural categories. In: Cognitive Psychology, No. 4 (3), pp. 328-350.

14. Russell, J. A. (1980). A circumplex model of affect. In: Journal of Personality and Social Psychology, No. 39 (6), pp. 1163-1168.

15. Russell, J. A. (2003). Core affect and the psychological construction of emotion. In: Psychological Review, No. 110 (1), p. 147.

16. Scherer, K. R. (2005). What are emotions? And how can they be measured? In: Social Science Information, No. 44 (4), pp. 698-700.

17. Van Kleef, G. A. and Côté, S. (2007). Expressing anger in conflict: When it helps and when it hurts. In: Journal of Applied Psychology, No. 92 (6), pp. 1562-1567.

18. Västfjäll, D., Friman, M., Gärling, T. and Kleiner, M. (2002). The measurement of core affect: A Swedish self-report measure derived from the affect circumplex. In: Scandinavian Journal of Psychology, No. 43 (1), pp. 19-31. 


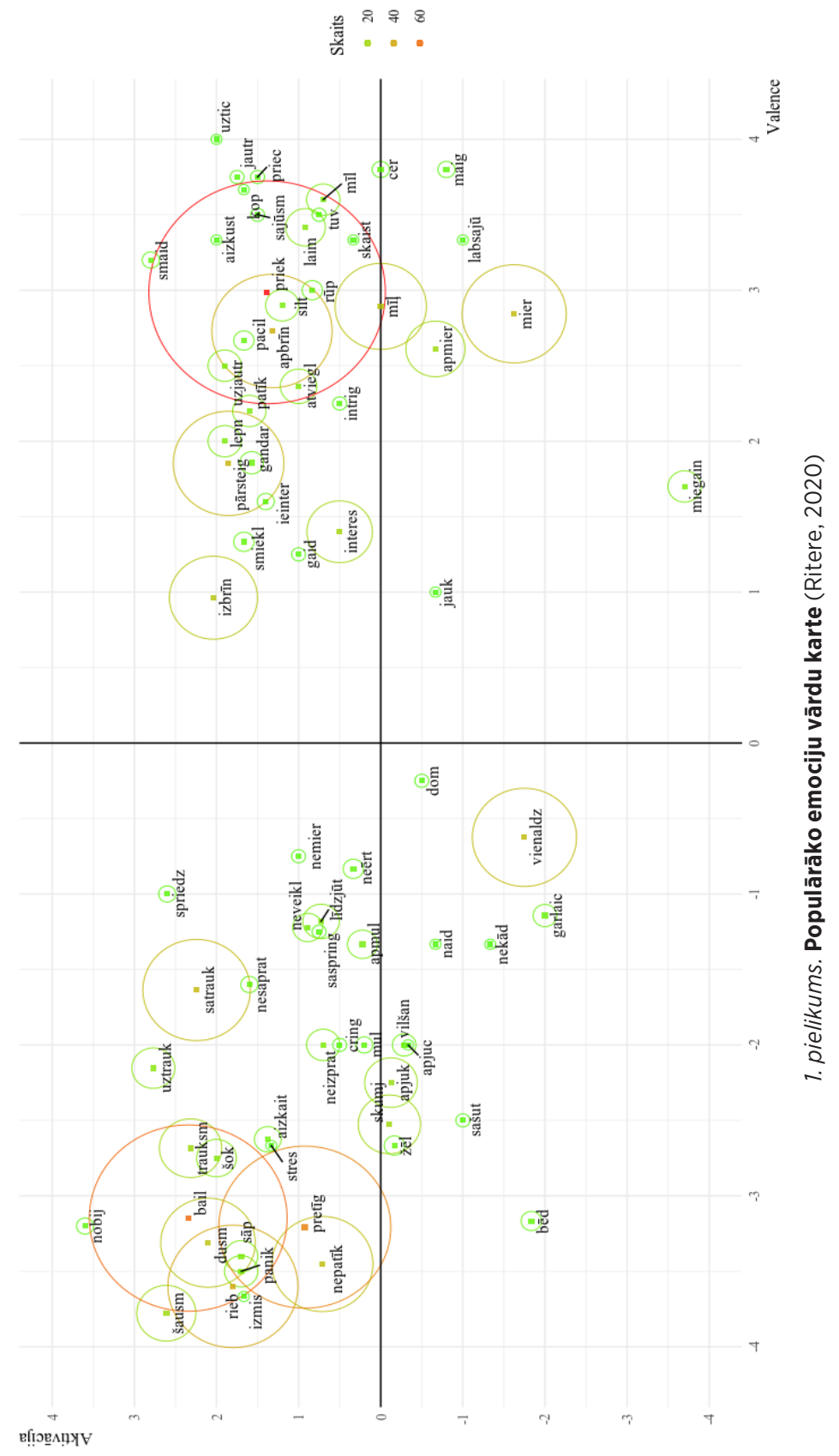

D. Ritere. Emocijas un afekts: vārdos, izjūtās, vērtējumos 


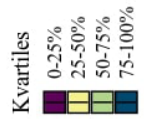

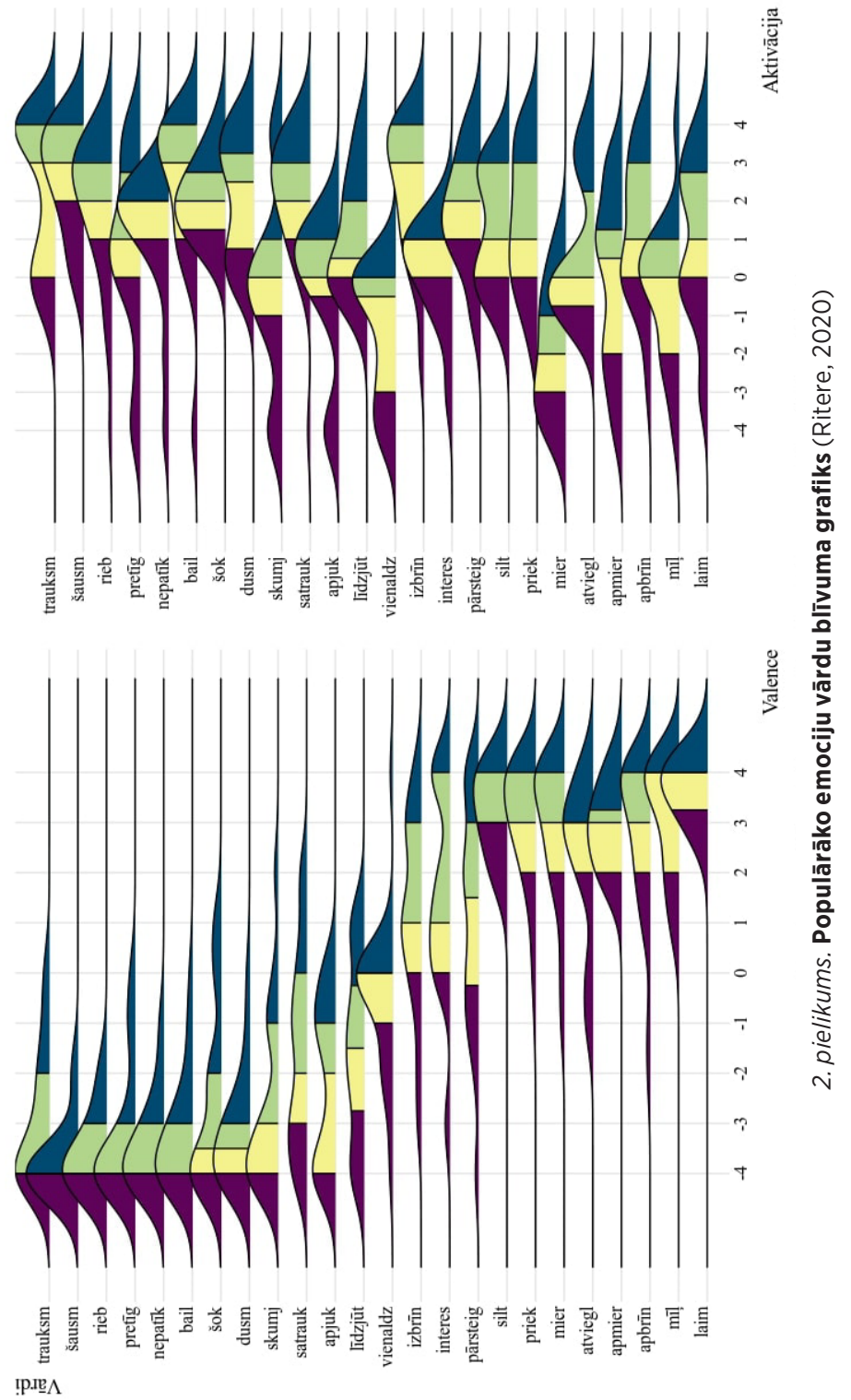



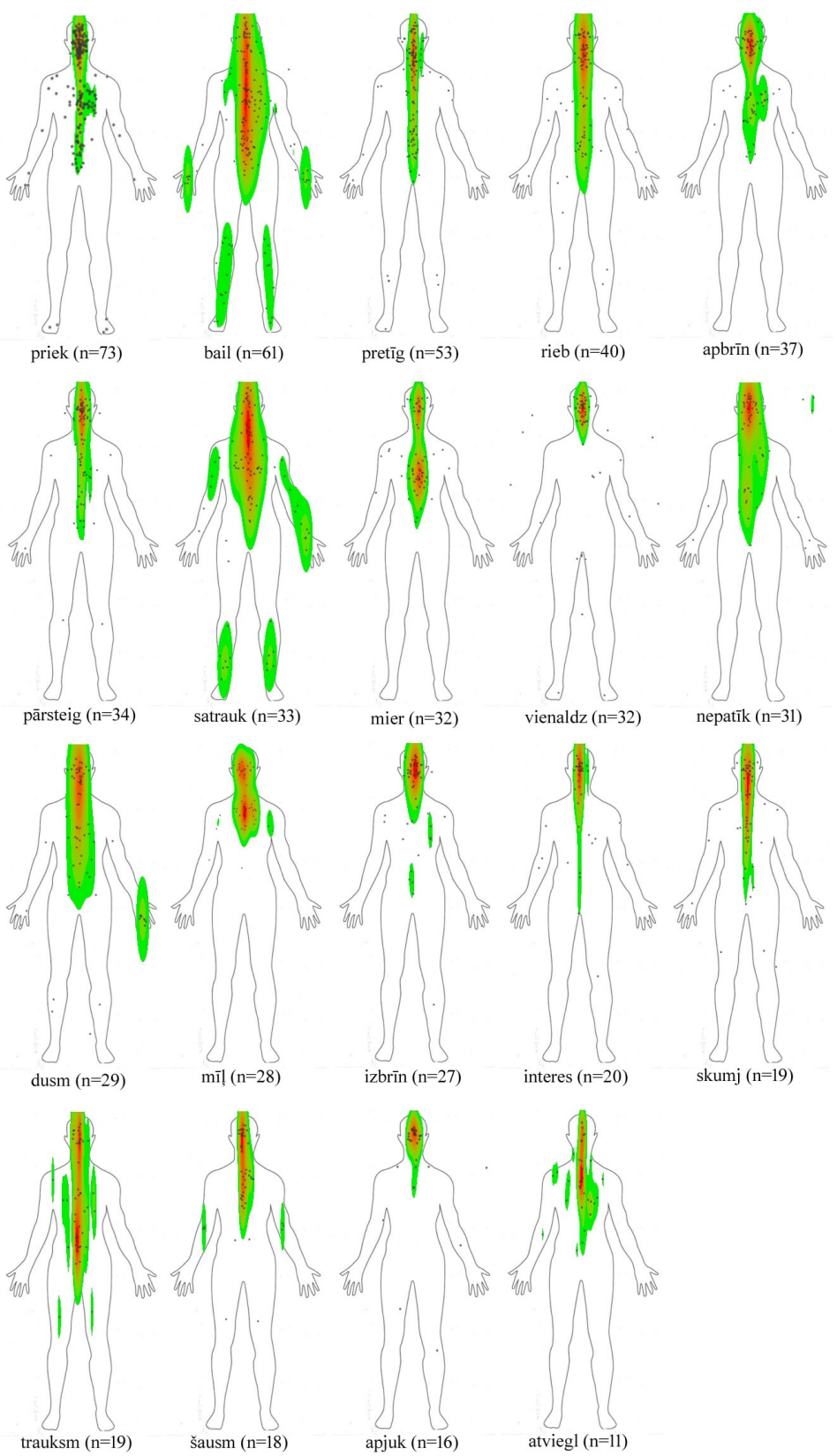

3. pielikums. Emociju vārdu k̦ermenisko izjūtu pašnovērtējuma attēlojums (Ritere, 2020) 